Bisset, K. A. (1959). J. gen. Microbiol. 20, 89-90

\title{
Some Characters of Rhizobium Strains from Tropical Legumes
}

\author{
By K. A. BISSET \\ Department of Bacteriology, University of Birmingham
}

\begin{abstract}
SUMMARY: Twelve strains of Rhizobium sp. from wild and cultivated leguminous plants growing in the Belgian Congo were examined. All were bacillary or filamentous, weakly Gram-positive, and produced occasional refractile, heat-resistant spores; all grew alternatively in the form of very tiny, Gram-negative rods with polar flagella (if motile), and without spores. Botanical evidence suggests that the host plants are primitive members of the family Leguminosae, and if the characters of these strains of Rhizobium are also to be regarded as primitive, this evidence supports the view that Rhizobium is related to Azotobacter and the Bacillaceae.
\end{abstract}

It was suggested (Bisset, 1952) that Rhizobium is an aberrant genus of Bacillaceae, related to Bacillus polymyxa, and further (Bisset, 1955), that the genus Azotobacter and the nitrogen-fixing clostridia are all members of the same relatively close group. Support for this theory has recently been provided by Hino \& Wilson (1958), who have shown that nitrogen is fixed by bacilli which closely resemble Bacillus polymyxa. In an analytical review, Norris (1956) brought evidence that the tropical genera of Leguminosae, the host plants of the Rhizobium symbionts, are relatively primitive, and that their strains of Rhizobium (the so-called cow-pea type) may also be primitive. It is thus of interest to examine the characters of Rhizobium from tropical legumes, in order to discover whether these are especially suggestive of a relationship with the Bacillus polymyxa group; and this proves to be the case.

\section{METHODS}

Twelve isolates of Rhizobium from tropical legumes in the Belgian Congo were obtained by the kindness of Dr C. Bonnier from the collection maintained in the Institut Agronomique, Gembloux, for experimental purposes, including cross-inoculation studies; the host plants were in the genera Arachis, Desmodium, Stylosanthes, Pueraria, Vigna, Canaralis, Mimosa, Calopogonium, Afrormosia, Crotalaria, Pterocarpus and Deweraea, of which the first six are cultivated plants, and the remainder wild. The bacteria were cultivated on cooked potato slopes, upon which they grew luxuriantly at $20^{\circ}$.

\section{OBSERVATIONS}

As with most strains of the genera Rhizobium and Azotobacter, these bacteria grew unpredictably in more than one morphological phase. In this case they were all very similar and adopted two forms. When repeatedly subcultured they grew as large, rather irregular, weakly Gram-positive bacilli and filaments, 
up to $\mathbf{1 . 5} \mu$ in diameter, with very occasional refractile spores. When subcultured at intervals of a week or longer they grew mainly as exceedingly tiny, Gram-negative rods, $c .0 \cdot 3 \mu \times 1 \mu$. Under the electron microscope these could be observed to have polar flagella, usually two in number, but not in some isolates, e.g. that from Mimosa. These minute bacilli resembled the gonidia of other Rhizobium spp. (Bisset, 1952) rather than the bacterium-like growth form typical of isolates from cultivated temperate-zone plants; but they resembled the latter in that they were capable of reproducing indefinitely in this phase. The bacterium-like forms were seen, but only very occasionally.

Five isolates were tested for heat resistance. In the sporogenous phase they survived $20-30 \mathrm{~min}$. at $80^{\circ}$. In the minute phase they failed to survive $50^{\circ}$ for more than a few minutes.

Biochemical reactions were, as with other strains of Rhizobium, very variable. Six either failed to grow in peptone water sugars or to ferment any sugar; the remainder fermented glucose, mannitol and sucrose, but never dulcitol; four produced acid, and two, acid and gas after 14 days. Culturally they resembled other Rhizobium, with pale mucoid colonies.

\section{DISCUSSION}

The twelve isolates of Rhizobium from supposedly primitive tropical legumes were morphologically much alike and showed characters suggestive of phylogenetic primitiveness, on the theory that the ancestral form resembled Bacillus polymyxa. All were capable of adopting a weakly Gram-positive bacillary or filamentous form, and produced spores. Some produced acid and gas from carbohydrates. Similar characters are found, but less regularly, in European Rhizobium (Bisset, 1952), and these adopt very freely a bacteriumlike form which in the tropical strains is much less common. Both produce tiny, polar-flagellate swarmers, as do numerous other types of bacteria, notably Azotobacter. It is worthy of emphasis that these tropical Rhizobium, although showing very obvious and regular signs of their relationship with the sporing bacilli, are nevertheless entirely distinct from any common species of Bacillus. By comparison with temperate-zone strains they are much less variable in their morphology, although still much more so than saprophytic bacilli.

\section{REFERENCES}

Bisset, K. A. (1952). Complete and reduced life-cycles in Rhizobium. J. gen. Microbiol. 7, 233.

Bisset, K. A. (1955). Evidence from the cytology of Azotobacter chroococcum of a relationship with Rhizobium and the Bacillaceae. J. gen. Microbiol. 13, 443.

Hino, S. \& Wilson, P. W. (1958). Nitrogen fixation by a facultative bacillus. $J$. bact. 75, 403.

Nornis, D. O. (1956). Legumes and the Rhizobium symbiosis. Emp. J. exp. Agric. 24, 247.

(Received 2 July 1958) 